\title{
COMPARAÇÃO ENTRE FORMAS DE EXTRAÇÃO DO TEMPO MÁXIMO FONATÓRIO EM INDIVÍDUOS SEM QUEIXAS VOCAIS
}

\section{Comparison of methods to extract the maximum phonation d uration in individuals without vocal complaints}

\author{
Marina Englert( ${ }^{(1)}$, LorianeGratão Mesquita ${ }^{(2)}$, Renata Azevedo ${ }^{(3)}$
}

\begin{abstract}
Purpose: to check the credibility between an acoustic program, an experienced evaluator and a nonexperienced evaluator measuring the Brazilian vowel /a/ in subjects with no voice complaints and to verify if there is difference between the highest value of three emissions of MPD with the average of these values. Methods: 56 adults recorded the vowel /a/ in MPD. One measurement was performed by an experienced speech pathologist and the other by a newly graduated speech pathologist, with a stop watch. A third valuator measured the MPD in an acoustic program. The difference between the average of the three emissions and the highest value of MPD obtained by each evaluator was compared. Results: there was no difference between the evaluators and an acoustic program the only difference found was among considering the average of the three emissions or the highest value of MPD. Conclusions: the MPD has high reliability regardless the form of extraction and the clinical experience of the evaluator. There was a difference in the value of MPD comparing the average of three emissions with its highest value, which suggests that we should always follow the same pattern in our assessments and reassessments.
\end{abstract}

KEYWORDS: Voice; Phonation; Health Evaluation

\section{INTRODUCTION}

The maximum phonation duration (MPD) is a highly reliable acoustic measure ${ }^{1}$ that allows a qualitative and quantitative evaluation of phonation based on a sustain vowel or connected speech, at maximum expiration ${ }^{2}$. This measure integrates functions of the respiratory system, phonatory system and suffers influences from the central nervous system ${ }^{3}$. The MPD offers data from speech functions, exploring the phonatory and expiratory abilities and control ${ }^{4-6}$. Its emission should occur at normal pitch and loudness ${ }^{7,8}$.

(1) Department of Speech Language Pathology at Federal University of Sao Paulo - UNIFESP, Sao Paulo, SP, Brazil.

(2) Department of Speech Language Pathology at Federal University of Sao Paulo - UNIFESP, Sao Paulo, SP, Brazil.

(3) Department of Speech Language Pathology at Federal University of Sao Paulo - UNIFESP, Sao Paulo, SP, Brazil.

Conflict of interest: non-existent
The MPD is widely used in clinical practice for diagnostic and therapeutic evolution, since the sustained emission provides characteristics such as type of vocal attack and vocal stability, it is an efficiency test, very practical, fast and cheap ${ }^{2,4,7,9,10}$.

The vowel / a / is the one that most evident dysphonia, because it makes evident the minimum balance changes at the larynx, being the most valuable vowel for the vocalevaluation ${ }^{5,10}$.

Values below 10 seconds are considered significantly altered ${ }^{7,11}$ and indicative of poor airflow. Increased values are indicative of a lot of muscle tension at phonation ${ }^{6}$.

Irregular MPD values may indicate presence of various disorders of the larynx, from incomplete glottal closure to vocal folds paralysis suspicion. Studies $^{6,10}$ found low MPD values are related to laryngeal pathology, due to difficulties with glottic closure with larynx lesions. Altered values also indicate poor coordination while breathing and 
speaking, requiring constant air recharge during connected speech, which tends to generate fatigue and hyperventilation, resulting in complaints such as breathlessness ${ }^{6,7}$. MPD indirectly indicates the ability to sustain long sentences ${ }^{3,8}$.

This study aims to check the credibility of the MPD measurement of a sustained vowel in subjects without vocal complaints between an acoustic program, an experienced evaluator and an inexperienced evaluator. This study also aims to check for statistical difference when comparing the average of three measurements of MPD and its highest value.

\section{METHODS}

This study was approved by the Ethics Committee and Research of the Federal University of Sao Paulo (UNIFESP) under the number 192040.

56 adults without vocal complaints were voluntarily recruited to record the Brazilian vowel / a /, at MPD. All subjects read and signed an informed consent form. The oldest participant in the study was 50 years old and the youngest 18 years old. The average age was 23 years old. The study included 54 women and 2 men. Inclusion criteria were patients over 18 years old and with no vocal complaints.

Three evaluators measured the MPD of the same vowel / a / produced by each participant. Two measurements were made using a digital stopwatch and one using acoustic analysis software, Sound Forge version $4.5 \mathrm{c}^{12}$. The three evaluators performed the measurements at the same time, without any visual contact between them. Therefore, the evaluators were not influenced by the other evaluator's measurements.

The evaluators were standing next to each other and facing the subject who was seated in front of them, inside a sound-treated booth. There was a partition between the evaluators.

The individual was instructed by one of the evaluators to breathe deeply and issue the vowel / a / as long as possible. This statement was repeated three times, with 15 seconds rest between each one.
One evaluator recorded the issues directly on the computer, using the acoustic analysis software Sound Forge, version $4.5 \mathrm{c}^{12}$, and extracted the measurement of MPD from the recording made by the program. Another evaluator, a speech language pathologist with over 20 years of experience, measured the MPD with a digital stopwatch. The third and last evaluator, a newly graduated speech pathologist, measured the MPD also using a stopwatch.

The MPD values were organized in the Office 2010 Excel spreadsheet according to who produced it and how the measurement was made (digital stopwatch used by an experienced speech pathologist, digital stopwatch used by an inexperienced speech pathologist and the acoustic analysis software). Another spreadsheet contained the largest MPD produced by each individual and the average of the three emissions. Statistical analyses of these data were made by SPSS V17, Minitab 16 and Office Excel 2010.

The values extracted by each evaluator were statistically compared to verify if there was difference in these values due to the experience of the evaluator and the acoustic analysis software. For this analysis the ANOVA test was used. The highest value of MPD obtained for each individual and the average of the three resulting emissions were also compared to verify whether there was a statistical difference between these two values. For this second analysis, the T-Student test was used. The level of significance consider for the Average was $0.05(5 \%)$. All confidence intervals built during the project were built with $95 \%$ statistical confidence.

\section{RESULTS}

Table 1 presents the average, confidence interval and standard deviation obtained from the MPD, relating the acoustic analysis program with the experienced evaluator and with the inexperienced evaluator. Figure 1 shows and compares these same values shown in Table 1. 
Table 1 -Average, confidence interval and standard deviation obtained from the MPD, obtained by the acoustic analysis software, the experienced evaluator and the inexperienced evaluator

\begin{tabular}{lccc}
\hline MPD & Experienced & Inexperienced & $\begin{array}{c}\text { Acoustic Analysis } \\
\text { Software }\end{array}$ \\
\hline Average & 12,25 & 12,28 & 12,25 \\
Cl & 0,89 & 0,88 & 0,85 \\
Standard Deviation & 3,4 & 3,35 & 3,24 \\
P-Value & & 0,999 & \\
\hline
\end{tabular}

Legend: MPD - maximum phonation duration; $\mathrm{Cl}$-confidence interval; * $\mathrm{P}=0,999-$ for ANOVA Test

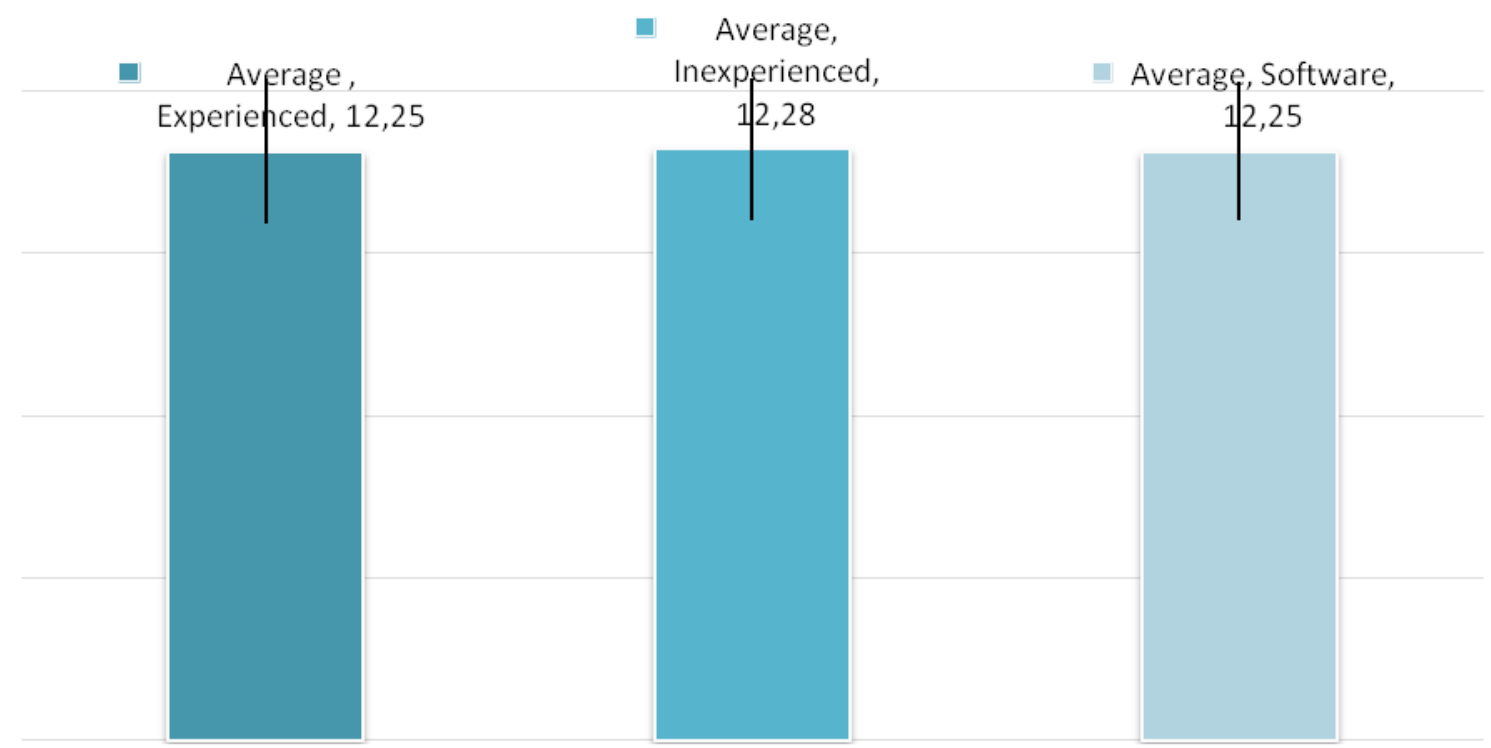

Legend: ${ }^{*}=0,999-$ for ANOVA Test

No statistically significant difference between the evaluators and the acoustic analysis software for the average of MPD was found. All three equally measured the MPD value.

Figure1- Comparison from the values obtained by the experienced evaluator, the inexperienced evaluator and the acoustic analysis software

There is no statistically significant difference between the evaluators and the acoustic analysis software for the average of MPD. Thus, all three equally measured the MPD value, which indicates that the method used for measurement, does not interfere in the final value of MPD.

Table 2 shows the average, confidence interval and standard deviation obtained by acoustic analysis software and compares the average of the MPD with the highest value obtained for each subject. Figure 2 shows and compares these same values shown in Table 2.

The mean difference of 12.10 seconds obtained in the method by average to 13.49 seconds obtained in the method of highest value is considered statistically significant. 
Table 2 - Average, confidence interval and standard deviation obtained by acoustic analysis software to compare the average of the MPD three issues with the highest value obtained for each subject

\begin{tabular}{ccc}
\hline Acoustic Analysis Software & Average from Three Issues & Highest Value \\
\hline Average & 12,1 & 13,49 \\
Cl & 0,93 & 1,01 \\
Standard Deviation & 3,57 & 3,86 \\
P-Value & & $<0,001$ \\
\hline
\end{tabular}

Legend: Cl-confidence interval; * $\mathrm{P}<0,001$ - for T-Student test

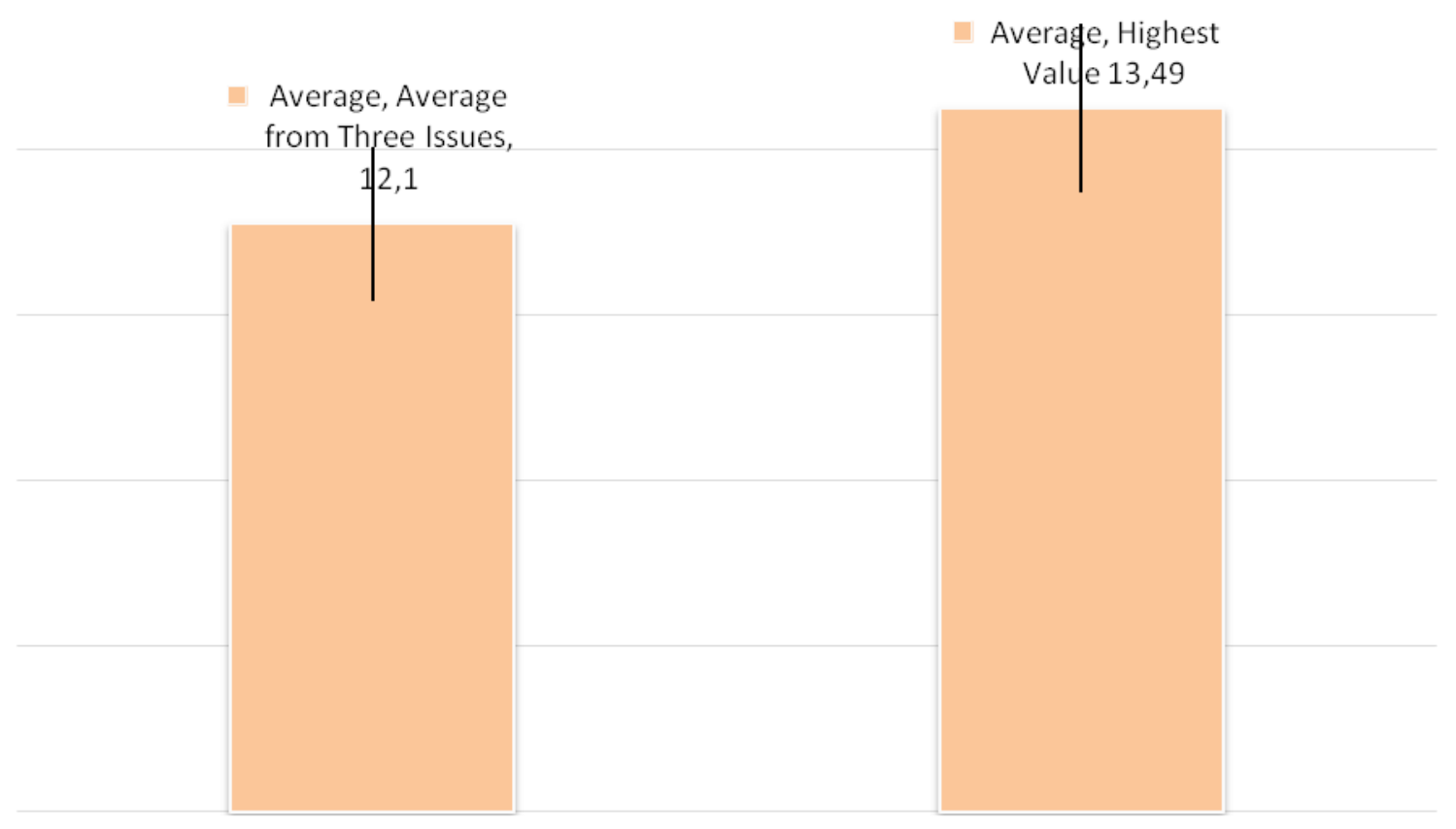

Legend: * $\mathrm{P}<0,001$ - for T-Student test

The mean difference of 12.10 seconds obtained in the method by average to 13.49 seconds obtained in the method of highest value is considered statistically significant.

Figure2 - Comparison of the values obtained by the average from three issuses and highest value

\section{DISCUSSION}

It only takes a stopwatch and an audio recorder to extract the MPD2. Several authors ${ }^{1,5,8,9,13}$ used only a stopwatch to define this measure in their research, yet, many programs can provide it, also performing other analyzes. The advantage of using acoustic analysis software is that there is no bias in the time it takes for the evaluator to push the timer button, when beginning and finishing the issue. The software allows the user to select the exact portion of the issuance and provides its exact duration.

To extract the MPD, some authors ask for three issues of each vowel and for analysis use the highest obtained value $e^{4,6,8,13,14}$, others authors ${ }^{5,9}$ choose to extract the average of these three values A study ${ }^{1}$ found that a single measurement of MPD is enough to find a highly reliable value. The authors assessed the efficacy of this measure on different days and concluded that the MPD is a highly reliable measure for voice evaluation. The present study can conclude that MPD is also reliable regardless of who extracts it, experienced evaluator or inexperienced evaluator. It is noteworthy that, in this study, all subjects received the same instruction from the same evaluator, which usually reproduce the clinical practice reality.

The comparison between the highest value of MPD obtained for each individual and the average of the three emissions, presented 
statistically significant difference, which shows that the MPD of an individual can vary according to which measurement the evaluator considers, average or highest value. As already mentioned, the literature shows no consensus for use of the highest value or the average of three emissions. It was observed, however, that most of these studies ${ }^{4,6,8,13,14}$ decided to consider the highest value.

In the other hand, the study mentioned before ${ }^{1}$ concluded that a single value of MPD is sufficiently reliable to assess its real value for different subjects, which makes the three issues, commonly requested, unnecessary. Considering the study ${ }^{1}$ and the findings of the present study, it can be concluded that the MPD considered from the average of three emissions or from the highest value obtained, does not interfere in the clinical practice, if the evaluator always consider the same value, average or highest value.

As the aim of this study was to compare the different forms of MPD extraction, and not to find normal value for this measure, there was no concern to balance the sample related to gender and age. Thus, it was not negative that the sample included more women than men, the ages vary from 18 to 50 years old and that there were 16 emissions below 10 seconds, considered as altered.

Assessment of MPD is extremely common and important in clinical speech language pathology practice, whether for diagnostic, prognostic or therapeutic evolution. The present study allowed us to find that this measurement is not influenced according to the evaluator's experience or the equipment used, and that each evaluator should follow a pattern for its assessment and reassessment, avoiding biases. Thus, this study shows that when analyzing MPD measures, they are highly reliable, regardless the extraction methods (stopwatch or acoustic analysis software) and the clinical experience of the speech language pathologist.

\section{CONCLUSIONS}

The MPD has a high reliability regardless the form of extraction (acoustic analysis software or stopwatch) and the clinical experience of the evaluator(over 20 years of experience or newly graduated). There was a difference in the value of MPD comparing the average of three emissions with its highest value, which suggests that clinical should always follow the same pattern in their assessments and reassessments.

\section{ACKNOWLEDGEMENT}

To UNIFESP for the space to perform this study, and to all the subjects who were willing to participate in this project.

\section{RESUMO}

Objetivo: verificar a confiabilidade entre um programa de análise acústica, um avaliador com experiência e um avaliador sem experiência na área para medição do TMF da vogal /a/ em sujeitos sem queixas vocais. Verificar se há diferença entre o maior valor das três emissões do TMF com a média desses valores. Métodos: 56 adultos realizaram emissão e gravação da vogal /a/ em TMF. Uma medição foi realizada por um fonoaudiólogo com experiência e outra por um fonoaudiólogo recém-formado, ambos utilizando um cronômetro. Um terceiro avaliador realizou a medida em um programa de análise acústica. Comparou-se a diferença entre os valores encontrados para a mesma emissão e o maior valor de TMF obtido com a média resultante das três emissões para cada indivíduo. Resultados: não houve diferença entre os avaliadores e o programa de análise acústica. Há diferença estatisticamente significante na definição do TMF, considerando-se a média das três emissões ou seu maior valor. Conclusão: o TMF tem grande confiabilidade independentemente da forma de extração e da experiência clínica do avaliador. Houve diferença no valor do TMF quando comparado à média de três emissões com a maior emissão, o que sugere que se deve sempre seguir o mesmo padrão nas avaliações e reavaliações, evitando vieses.

DESCRITORES: Voz; Fonação; Avaliação em Saúde 


\section{REFERENCES}

1. Speyer R, Bogaardt HCA, Passos VL, Roodenburg NPHD, Zumach A, HeijnemMAMetal. Maximum phonation time: variability and reliability. JVoice. 2010;24(3):281-4.

2. Maslan J, Xiaoyan L, Rees C, Blalock D, Butler SG. Maximum phonation time in healthy older adults. J Voice. 2011;25(6):709-13.

3. Edgar J. Effects of eating on professional and amateur singers for select pulmonar and vocal tasks. J Voice. 2008;22(6):721-6.

4. SolomanNP,ShannonJG,Milbrath RL. Respiratory and laryngeal contributions to maximum phonation duration. JVoice. 2000;14(3):331-40.

5. Rossi DC, Munhoz DF, Nogueira CR, Oliveira TCM, Britto ATBO. Relação do pico de fonação em pacientes asmáticos. Rev CEFAC. 2006;8(4):509-17.

6. Beber BC, Cielo CA, Siqueira MA. Lesões de borda de pregas vocais e tempos máximos de fonação. Rev CEFAC. 2009;11(1):134-41.

7. Behlau M, Madazio G, Feijó, Pontes P. Avaliação de voz. In: Behlau M. Voz- O livro do especialista,
Volume I. Rio de Janeiro: Revinter; 2001 Reimpressão 2008. p. 85 - 245.

8. Miglioranzi SH, Cielo CA, Siqueira MA. Capacidade vital e tempos máximos de fonação de /e/ áfono e de /s/ em mulheres adultas. Rev CEFAC. 2012;14(1):97-103.

9. Cerceau JSB, Alves CFT, Gama ACC. Análise acústica da voz de mulheres idosas. São Paulo. Rev CEFAC. 2009;11(1):142-9.

10. KurtzLO,Cielo CA. Tempo máximo de fonação de vogais em mulheres adultas com nódulos vocais. Pro Fono R Atual Cient. 2010;22(4):451-4.

11. Cielo CA, Casarin MT. Sons fricativos surdos. Rev CEFAC. 2008;10(3):352-8.

12. SonicFoundry. SoundForge [Programa de Computador]. Versão 4.5c, de http://www. sonycreativesoftware.com/soundforge 13. MiglioranziSH,Cielo CA, Siqueira MA. Relação entre capacidade vital, tempo máximo de /e/ emitido de forma áfona, de /s/ e estatura em mulheres adultas. Rev CEFAC.2011;13(6):1066-72.

14. Cielo CA, Conterno G, Carvalho CDM, Finger LS. Disfonias relação s/z e tipos de voz. São Paulo. Rev CEFAC. 2008;10(4):536-47.

Received on: August 08, 2013

Accepted on: November 11, 2013

Mailing address:

Marina Englert

Alameda Everest 120, Tamboré 2,

Santana de Parnaíba

São Paulo - SP - Brasil

CEP: 06543-135

E-mail: marinaenglert@gmail.com 